effective vehicle for a placebo effect, the physician-patient relationship is generally preferable." 15 But if, as Prioleau et al maintain, the relationship is itself a form of placebo-if the medium constitutes the message-then the problems of evaluation become more complex. Several of the difficulties emerged from an ill fated Medical Research Council trial some 10 years ago, ${ }^{16}$ though other studies have since shown that at least some of the obstacles can be overcome. ${ }^{17}$ Unfortunately, most of the major research bodies in Britain appear to fight shy of the topic, and the professional organisations, including the Royal College of Psychiatrists, have done little more than pay lip service to the need for action. With its broader view of hygiene and its professed concern for the consumer, perhaps the new College of Health might be prepared to confront the issues more directly?

MichaEl Shepherd

Professor of Epidemiological Psychiatry,

Institute of Psychiatry,

London SE5 8AF

1 Prioleau L, Murdoch M, Brody B. An analysis of psychotherapy versus placebo studies. The Behavioral and Brain Sciences 1983;6:275-85.

${ }^{2}$ Frank JD. The placebo is psychotherapy. The Behavioral and Brain Sciences 1983;6:291-2.

${ }^{3}$ Maher B. Meta-analysis: we need better analysis. The Behavioral and Brain Sciences 1983;6:297-8.

4 McGuire TG. Markets for psychotherapy. In: Vandenbos GR, ed. Psychotherapy: practice, research, policy. Beverly Hills: Sage Publications, $1980: 187-245$.

${ }^{5}$ London P, Klerman GL. Evaluating psychotherapy. Am $\mathcal{f}$ Psychiatry 1982;139:709-17.

${ }^{6}$ Shepherd M. Psychoanalysis, psychotherapy, and health services. Br Med $\mathcal{f}$ 1979 ;ii:1557-9.

${ }^{7}$ Shepherd M. The statutory registration of psychotherapists? Bulletin of the Royal College of Psychiatrists 1980;4:166-8.

${ }^{8}$ Report of Psychotherapy Section Executive Committee. Statutory registration of psychotherapists. Bulletin of the Royal College of Psychiatrists 1983;7:190-5.

9 Wilkinson G. Psychotherapy in the marketplace. Psychol Med (in press).

${ }^{10}$ Foster JG. Enquiry into the practice and effects of scientology. London: HMSO, 1971

11 Janet P. Les médications psychologiques. 3 vols. Paris: Alcan, 1919.

12 Tuke DH. Illustrations of the influence of the mind upon the body in health and disease. 2nd ed. London: J \& A Churchill, 1884:287.

13 Jospe $M$. The placebo effect in healing. Lexington, Mass: Heath and Co, 1978.

${ }^{14}$ Lindahl O, Lindwall L. Is all therapy just a placebo effect? Metamedicine $1982 ; 3: 255-9$.

${ }^{15}$ Gilman AG, Goodman LS, Gilman A, eds. The pharmacological basis of therapeutics. 6th ed. New York: Macmillan, 1980.

${ }^{16}$ Candy J, Balfour FHG, Cawley RH, et al. A feasibility study for a controlled trial of formal psychotherapy. Psychol Med 1972;2:345-62.

17 Sloane RB, Staples FR, Cristol AH, Yorkston NJ, Whipple K. Psychotherapy versus behavior therapy. Cambridge, Mass: Harvard University Press, 1075.

\section{Pharmacy: an inquiry into its contribution to patient care}

Medicine and pharmacy have common roots, and their responsibilities remain complementary, the patient depending on the pharmacist to supply the medication prescribed by his doctor. Despite some minor feuds (such as those associated with dispensing doctors in rural areas), major changes in either profession must inevitably have important consequences for the other; certainly both will want to examine the proceedings and conclusions of the recently announced Nuffield Foundation Pharmacy Inquiry.

The status of pharmacists in hospitals has improved considerably during the past decade-since the Noel Hall report $^{1}$ and the subsequent reorganisation of the Health Service. Clinical pharmacy has not developed in Britain in the same mould as in some centres in the United States, but nevertheless ward pharmacy has been established in many hospitals, pharmacists are often included in the membership of drugs and therapeutics committees, and the hospital pharmacy is often the source of local drug information-for general practitioners as well as hospital staff.

Whereas only 3700 pharmacists work in hospitals, about 18000 are in community (retail) pharmacy, which seems likely to receive most of the attention of the committee of inquiry. In recent years the retail pharmacist has abandoned his measuring of quantities of liquid medicines, counting of tablets into bottles, or even preparing galenical formulations himself; instead, he now usually dispenses drugs prepared and packaged by their manufacturers. Furthermore, though most non-prescription drugs are available only from a pharmacy, some common symptomatic remedies such as aspirin and paracetamol may be bought in supermarkets without the supervision for which the pharmacist has always sought and accepted responsibility.

Retail pharmacy has predictably responded to these changes in several ways. Most pharmacists have diversified into other retail lines, some remote from health care. A few have attempted to present a more responsible and specialised image, restricting their activities entirely to drug dispensing and setting up patient record systems comparable with those of their medical practitioner colleagues. Which way is retail pharmacy to go? The answer is crucial for the future of pharmacy education.

Many pharmacists believe very strongly that "a pharmacist is indeed the leading authority on drugs and medicines, their chemistry, and their pharmacology."2 One has even composed a mantra to be "muttered" every morning: "I am the person who knows all about medicines, and I am not giving way to anyone else on that subject." Such an attitude ignores the inseparable relation between a medicine and the disease it was designed to treat. Present education in pharmacy does not equip its graduates with an adequate basic understanding of pathology and therapeutics. Certainly several postgraduate diploma and master's courses in clinical pharmacy are now available which provide such teaching to relatively few, and larger numbers of pharmacists attend less formalised introductory courses to clinical medicine, but the clinical content of the undergraduate schools of pharmacy (some of them in universities, others in polytechnics) is very variable. Few schools of pharmacy include experience of contact with the patient-customer in their undergraduate practical courses. My own experience suggests that clinical concepts and terminology are better understood by the pharmacy graduates of some polytechnic departments than by those from well known university departments, whose academic research interests may be remote from the therapeutic use of medicines in sick patients.

Clearly the pharmaceutical profession wants to be more intimately and responsibly concerned in the care of patients. Doctors must not ignore or shrug off this desire. Many pharmacists entered their profession because they saw it as an alternative to medicine when their attempts to enter medical schools were unsuccessful. The Pharmaceutical Society of Great Britain has recently been looking closely at what the response of the retail pharmacist should be to the patient's symptoms. A College of Pharmacy Practice has been set up to scrutinise and supervise postgraduate professional 
practice and further education in pharmacy. The trustees of the Nuffield Foundation have now set up their committee of inquiry, which includes three medical representatives, which will "consider the present and future structure of the practice of pharmacy in its several branches and its potential contribution to health care and to review the education and training of pharmacists accordingly." The committee has invited evidence (by 30 April) from "interested individuals and organisations both inside and outside the [pharmaceutical] profession." 3 The results of the inquiry will be far reaching and the face of retail pharmacy, and perhaps of other branches of the profession, may well change appreciably over the next decade as a result. Pharmacy has its own special contribution to make to the development of new drugs within the pharmaceutical industry and to their provision to patients in hospitals and in the community with appropriate guidance on their use and storage; it will also play its part in the wider dissemination of health education in general to the community. The Nuffield inquiry must consider carefully all these aspects of pharmacy practice. The present problems in pharmacy, and indeed in the National Health Service as a whole, will be resolved only if all who participate in it experience a sense of fulfilment, that the job they are doing is essential and responsible, and that their own particular contribution to health care is appreciated both by the patient and by the community.

\section{PAUL TURNer}

Professor of Clinical Pharmacology,

St Bartholomew's Hospital,

London EC1A 7BE

' Anonymous. Noel Hall report on the hospital pharmaceutical service. Pharmaceutical fournal 1970;204:217-28.

2 Anonymous. Vive Martindale. Pharmaceutical fournal 1983;231:627.

${ }^{3}$ Anonymous. Health and Social Security Bill. Br Med f 1984;288:76-7.

\section{Acute stridor in the preschool child}

The sudden onset of stridor is a terrifying experience for the young child and his parents-and may cause the general practitioner a great deal of anxiety. The possible diagnoses which face the doctor on arrival at the child's home, often in the middle of the night, are acute viral croup, acute epiglottitis, staphylococcal tracheolaryngobronchitis (pseudomembranous croup), ${ }^{1}$ a foreign body, or angioneurotic oedema. Angioneurotic oedema is relatively easy to exclude, as there will be evidence of soft tissue swelling elsewhere. Foreign bodies are more difficult, but usually the parents will state that the stridor was heralded by an attack of coughing, often when the child was running around with something in his mouth. In both these circumstances admission to hospital is mandatory.

Far more frequently there is a history of upper respiratory symptoms for one to three days preceding the onset of stridor and the diagnosis lies between viral croup and acute epiglottitis. Differentiating between the two is usually not difficult: most children with viral croup have had an upper respiratory tract infection for two to three days, are afebrile, and have stridor present only when upset; those with acute epiglottitis have a history of less than 24 hours, are obviously toxic, flushed, and febrile, tend to drool their secretions, and have severe stridor. If acute epiglottitis is diagnosed the doctor must accompany the child to hospital, for complete airway obstruction may develop within minutes.

Acute viral croup may present more of a dilemma for it is much more common than epiglottitis and rarely requires intubation (about 1\% of those children admitted to hospital). Nevertheless, those who are cyanosed or becoming exhausted, with stridor at rest, need immediate admission. Those with stridor only when upset may be left at home, provided that the parents are confident that they can cope and can get help rapidly if the child's condition deteriorates.

The widely accepted clinical features which differentiate acute viral croup from epiglottitis are not, however, totally reliable. In a recent survey of children with acute stridor admitted to intensive care units over four years, about a third of those with acute epiglottitis had a history of respiratory symptoms lasting more than 24 hours. In addition, children with acute viral croup occasionally had severe toxaemia and developed complete airway obstruction suddenly and unexpectedly. $^{2}$ Epiglottitis was diagnosed correctly by the attending general practitioner in less than a fifth of those in whom the diagnosis was made at intubation. The clinical picture may be complicated further by a third condition, staphylococcal tracheolaryngobronchitis, which shares the clinical features of both viral croup and acute epiglottitis but leads to the production of copious thick secretions which may be removed only by tracheal aspiration after intubation.

The management of stridor is going through a period of reassessment. The emergence of strains of Haemophilus influenzae resistant to ampicillin has led to most paediatric units giving intravenous chloramphenicol rather than ampicillin for the treatment of acute epiglottitis. ${ }^{3}$ Some intubate all their patients electively once the diagnosis has been confirmed at laryngoscopy; others are more conservative, but even then about two thirds of the children will be intubated. Systemic steroids are often given, although there is no evidence that they help. The response to treatment is rapid and some paediatricians extubate after less than 24 hours. ${ }^{4}$ Children with staphylococcal tracheolaryngobronchitis should be given antistaphylococcal drugs such as flucloxacillin ${ }^{1}$ and they will need intubation for several days to allow the secretions to settle.

Anecdotal evidence suggests that children with acute viral croup benefit from a warm, humid environment. There is no place for cold mist treatment, for not only is this distressing to the child but the cold mist developed by a jet nebuliser has no appreciable effect on humidity in the larynx and ultrasonically generated mists increase airway obstruction in children with abnormally labile airways. ${ }^{5}$ Nebulised adrenaline and phenylephrine reduce the obstruction for up to 30 minutes but may be followed by a rebound effect. ${ }^{6}$ This is therefore a treatment which should be confined to hospitals. ${ }^{7}$ Systemic steroids have been shown to modify the course of recurrent croup, ${ }^{8}$ a condition in which the children have an abnormally labile upper airway. ${ }^{9}$

By far the most important aspect of treatment, however, is to ensure that all children who are at risk of upper airway obstruction are admitted to units where facilities for intubation are available immediately. There can be few more tragic events than the death of a child by suffocation due to a localised and entirely remediable upper airway obstruction.

A D Milner

Professor of Paediatric Respiratory Medicine,

University Hospital,

Nottingham NG7 2UH 